American Journal of Environmental Sciences 6 (5): 416-421, 2010

ISSN 1553-345X

(C) 2010 Science Publications

\title{
Comparative Study of Water Quality at Different Peat Swamp Forest of Batang Igan, Sibu Sarawak
}

\author{
${ }^{1}$ Noraini Rosli, ${ }^{1}$ Seca Gandaseca, ${ }^{2}$ Johan Ismail and ${ }^{1}$ Mohd Iqbal Jailan \\ ${ }^{1}$ Department of Forestry, Faculty of Agriculture and Food Sciences, \\ ${ }^{2}$ Department of Animal Science and Fishery, Faculty of Agriculture and Food Sciences, \\ University Putra Malaysia Bintulu Sarawak Campus, 97008 Bintulu, Sarawak, Malaysia
}

\begin{abstract}
Problem statement: It is important to find the status of water quality at converted peat swamp forest into oil palm plantation. This study was conducted to find and determine the water quality at peat swamp forest of Batang Igan, Sibu Sarawak. This study presents a status on the water quality of peat swamp forest at the area. Approach: In-situ data and a total of 72 water samples were collected at four sampling stations (S1, S2, S3 and S4) in three different months of July, August and November 2009. In-situ data included temperature, conductivity, Dissolved Oxygen (DO), pH and Turbidity. Analysis for ammoniacal nitrogen $\left(\mathrm{NH}_{3}-\mathrm{N}\right)$, Biological Oxygen Demand (BOD), Chemical Oxygen Demand (COD) and Total Suspended Solids (TSS) were conducted in the laboratory. Results for water quality parameters are as follows, temperature range $\left(26.85-32.90{ }^{\circ} \mathrm{C}\right), \mathrm{pH}$ range $(3.03-3.84)$, DO range (1.99-8.05 mg/L), conductivity $\left(42.07-98.72 \mu \mathrm{S} \mathrm{cm}^{-1}\right)$, TSS range $\left(1-54 \mathrm{mg} \mathrm{L}^{-1}\right)$, turbidity (0.39-9.80 NTU), BOD range (0.5-9.8 $\left.\mathrm{mg} \mathrm{L}^{-1}\right)$, COD (0-17) and ammoniacal nitrogen (0.2-0.42 $\mathrm{mg}$ $\mathrm{L}^{-1}$ ). The Water Quality Index (WQI) which was calculated based on six water quality parameters namely dissolved oxygen, biological oxygen demand, chemical oxygen demand, $\mathrm{pH}$, ammoniacal nitrogen and total suspended solids, was representative of the state of water quality in Batang Igan peat swamp forest. Results: Based on WQI, S1 was categorized under Class III while S2, S3 and S4 were categorized under Class II. Conclusion: The physical-chemical parameters of water in Batang Igan peat swamp forest were in normal range or in class I and class II that is in good water status except for $\mathrm{pH}$ and dissolved oxygen for the water; however it is normal condition for peat water.
\end{abstract}

Key words: Water quality parameters, Biological Oxygen Demand (BOD), Chemical Oxygen Demand (COD), Dissolved Oxygen (DO), Total Suspended Solids (TSS), turbidity, pH, peat swamp forest, Water Quality Index (WQI), oil palm plantation, ammoniacal nitrogen, organic pollution, Hydrology, monochloramines

\section{INTRODUCTION}

Peat swamp forests are tropical moist forest, which grew and formed on a layer of dead leaves, wood and all parts of tree and plant. It is an accumulation of 100\% of pure organic material (Salimin et al., 2010). They comprise a unique ecosystem characterized by water logging that is low in nutrients and dissolved oxygen levels in acidic water condition.

Peat swamp forests are an important component of wetlands that are closely related between land and water, the transition zone or place where the water flow, nutrients cycling and sun energy which eventually form a perfect ecosystem of hydrology including soil and vegetation. Peat swamp forests provide benefits in variety of products from forestry, fisheries, water resources, ground water absorption, energy resources and also act as flood mitigation (United Nations Development Programme, 2006).

Water stored in the active layer or catotelm in peat swamps and the volumes remains constant for a long time if the peat is not disturbed by any activity. Most of the changes in water storage occurred in conjunction with the level of water table. It is estimated that the change in water storage is not more than $3-10 \%$ of it storage volume (Ingram, 1983). Water flows freely in the active layer of water or acrotelm. Water storage is critical to the balance of water in peat swamps and at surrounding areas. Logging activity, agriculture, peat extraction and destruction of peat swamp drainage activity also give a negative effect and bad implication on the hydrology (Hamilton, 2005).

Corresponding Author: Noraini Rosli, Department of Forestry Science, Faculty of Agriculture and Food Sciences,

University Putra Malaysia Bintulu Sarawak Campus, 97008 Bintulu, Sarawak, Malaysia 
The water in peat swamp is almost black in color. The main reason is the presence of an organic material from peat decomposition. The black water produced from contact of water with organic litter and debris such as leaves and wood in various and at different stages of decomposition. Humic acid and tannin is derived from the decomposition of lignin and it is a principal of coloring matter. All of this played very important role in maintaining water balance in the ecosystem of peat swamp forest ecosystem (Gasim et al., 2007).

Peat swamp forest is Malaysia's largest wetland type that is cover about $75 \%$ of the Malaysia total wetlands. There are more than $70 \%$ of the peat swamp forests are located in Sarawak, about 20\% in Peninsular Malaysia and the rest in Sabah (United Nations Development Programme, 2006). Peat swamp forests constitute an estimated 1.6 million ha in Sarawak and only $26 \%$ of the land is suitable for conventional commercial agriculture (Gandaseca et al., 2009). About a third of peat land areas in the coastal lowland of Sarawak have been converted for oil palm plantation that have causing the destruction of biodiversity, loss of soil and serious threat to the water resources in the peat swamp forests area (John, 2005).

Large amounts of the Batang Igan peat swamp forest have recently converted to oil palm plantation while a some section on peat swamp forest still remain intact. This study reports the water quality research findings at the peat swamp forest of Batang Igan, Sibu, Sarawak.

\section{MATERIALS AND METHODS}

Study area: Location of the study area is at Batang Igan, Sibu, Sarawak, Malaysia latitude $02^{\circ} 15^{\prime} \mathrm{N}$ and longitude $111^{\circ} 58^{\prime} \mathrm{E}$ (Fig. 1A-C). The area experience tropical climate and high air humidity with an annual rainfall more than $4000 \mathrm{~mm}$ during the year. Mean rainfall on July 2009 was $4.96 \mathrm{~mm} \mathrm{day}^{-1}$, August $6.50 \mathrm{~mm} \mathrm{day}^{-1}$ while in November $15.91 \mathrm{~mm}^{\mathrm{day}^{-1}}$. Mean temperature of the area is $\left(28 \pm 5^{\circ} \mathrm{C}\right)$. The tropical peat swamp forests in Sarawak also influenced by a hot climate and humid condition throughout the year (Satrio et al., 2009a).

Water sampling and water preservation: The samples of water was taken and collected from four stations in study area (Fig. 1C) in July, August and November 2009. Station 1 is a small river located in front of the main road that is the place to enter into oil palm plantation area. All water from rivers drains or irrigation canals in this oil palm plantation will be flow out through this river. Station 2 is a small river located in the oil palm plantation area.

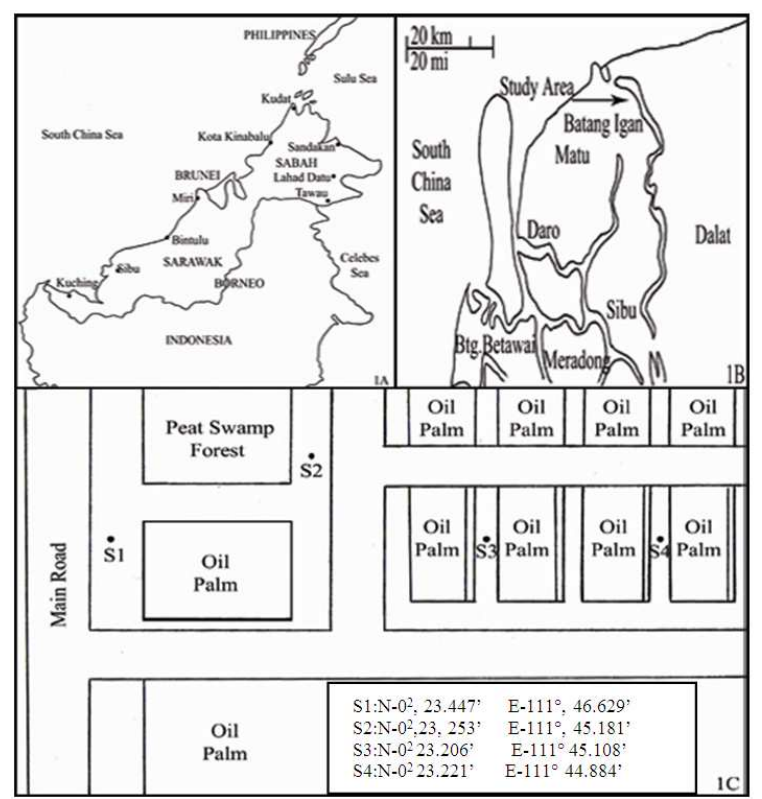

Fig.1: Location of the study area

It's located on the left side of the road. The depth of the river in Station 1 and 2 is about 2-3 m. While Station 3 and Station 4 is a man-made irrigation canals built to irrigate the area of oil palm plantation. Both of the station located in the middle of oil palm plantation. The depth of water in this irrigation is less than $1 \mathrm{~m}$. Water samples were collected from surface waters below 10 cm (Gupta, 2009) at each sampling station using plastic bottles $(500 \mathrm{~mL})$ and BOD bottles.

A total of six replicates of water samples were taken at each station. The water samples were kept in ice with further analyses at the laboratory. In situ data were recorded using Troll Multiparameter (Model 9500). The data included temperature, $\mathrm{pH}$, Dissolved Oxygen (DO), conductivity and turbidity. Other water quality parameter such as ammoniacal nitrogen $\left(\mathrm{NH}_{3}-\right.$ $\mathrm{N}$ ), Biological Oxygen Demand (BOD), Chemical Oxygen Demand (COD) and Total Suspended Solids (TSS) was analyzed in laboratory according to Standard Methods, APHA (2005).

Data analysis: Water classification was made possible by calculating the Water Quality Index or briefly known as WQI. WQI is very important parameter for evaluation and assessment of the surface (Yisa and Jimoh, 2010). The mean of Dissolved Oxygen (DO), Biological Oxygen Demand (BOD), Chemical Oxygen Demand (COD), pH, ammonical nitrogen $\left(\mathrm{NH}_{3}-\mathrm{N}\right)$ and Total Suspended Solids (TSS) is used to calculate the WQI. The values then converted to Sub Indices (SIs) 
using the best-fit equation by refers to the equation below to compute. The Water Quality Index (WQI) or status of the water then can be finding after completing the calculation according to the calculation formula (Wan Maznah and Manshor, 2002):

Water Quality Index (WQI) $=[0.22 \times$ Sub Index Dissolved Oxygen $]+[0.19 \times$ X Sub Index Biological Oxygen Demand $]+[0.16 \mathrm{X}$ Sub Index Chemical Oxygen Demand $]+[0.15 \mathrm{X}$ Sub Index Ammoniacal Nitrogen $]+[0.16 \times$ Sub Index Suspended Solids $]+$ [0.12 X Sub Index pH]

Statistical analysis of data was carried out using Statistical Analysis System (SAS) version 9.2. Comparison of mean for each parameter and mean comparison between stations was done by using Analysis of Variance (ANOVA).

\section{RESULTS}

The Table 1 present the data and result of each water quality parameters at four sampling station at study area in three month sampling. According to the results, the conductivity, turbidity, COD and TSS are in class I and the temperature, $\mathrm{pH}, \mathrm{DO}$, ammonia and BOD are in class III. The WQI for the study area was found to be under class III at S1 and class II at S2, S3 and S4.

Statistical analyses show that all water quality parameter were not significantly different between stations (ANOVA, $\mathrm{p}>0.05$ ). However the readings for DO and TSS at S4 were significantly higher (ANOVA, $\mathrm{p}<0.05)$ compare to other stations at the study area.

The temperature of the study area ranging from $26.85-32.90^{\circ} \mathrm{C}$ and the temperature readings were exceeding the standard water quality which is more than $18^{\circ} \mathrm{C}+2$ (standard for water supply) (Department of Environment, 2006). The mean value of temperature for S1 $(29.30 \pm 1.02) \mathrm{S} 2(29.31 \pm 1.67) \mathrm{S} 3(27.69 \pm 1.22)$ and S4 $(28.09 \pm 1.50)$. The mean temperature was $28.59^{\circ} \mathrm{C}$. ANOVA result showed that there is no significant difference $(p>0.05)$ on temperature between the stations.

The $\mathrm{pH}$ values ranged from $3.68 \pm 0.23$ (S3) to $3.80 \pm 0.12$ ( $\mathrm{S} 1)$ indicating an acidic water environment. In this study, $\mathrm{pH}$ of water showed no significant difference between stations (ANOVA, $\mathrm{p}>0.05$ ).

The concentration of Dissolved Oxygen (DO) of the water was ranged from 1.99 (S3) - 8.05 (S2) mg $\mathrm{L}^{-1}$. The mean value of DO for S1 $(3.99 \pm 1.44) \mathrm{S} 2$ (4.34 \pm 1.76$) \mathrm{S} 3(3.02 \pm 1.62)$ and S4 (4.13 \pm 0.43$)$. The mean DO was $3.87 \mathrm{mg} / \mathrm{L}$.

The readings for DO at $\mathrm{S} 4$ was significantly higher (ANOVA, $\mathrm{p}<0.05$ ) compare to other sampling stations at the study area.

Conductivity values ranged from 42.07-98.72 $\mu \mathrm{S}$ $\mathrm{cm}^{-1}$. The highest value obtained was $98.72 \mu \mathrm{S} \mathrm{cm}^{-1}$ recorded at $\mathrm{S} 2$ and the lowest value $42.07 \mu \mathrm{S} \mathrm{cm}^{-1}$ at S4. The mean value of conductivity for S1 $(63.0 \pm 6.62)$ S2 (83.43 \pm 23.69$)$ S3 $(88.40 \pm 9.67)$ and S4 (3.68 \pm 0.22$)$. The mean conductivity was $78.10 \mu \mathrm{S} \mathrm{cm}$. Overall, conductivity was categorized as Class I. When compared to the sampling stations, conductivity was not significantly different (ANOVA, $\mathrm{p}<0.05$ ).

The turbidity ranged from 0.3 (S4) - 9.80 (S1) NTU. The mean value of turbidity for S1 $(2.78 \pm 2.48)$ S2 $\quad(5.33 \pm 4.74) \quad$ S3 $\quad(2.67 \pm 2.20)$ and S4 $(1.27 \pm 0.70)$.There was no significant differences in turbidity between stations (ANOVA, $\mathrm{p}>0.05$ ).

The values of ammoniacal nitrogen $\left(\mathrm{NH}_{3}-\mathrm{N}\right)$ ranging from $0.01(\mathrm{~S} 2)-0.51(\mathrm{~S} 4) \mathrm{mg} \mathrm{L}^{-1}$. The mean value of $\mathrm{NH}_{3}-\mathrm{N}$ for $\mathrm{S} 1(0.32 \pm 0.09), \mathrm{S} 2(0.18 \pm 0.15), \mathrm{S} 3$ $(0.18 \pm 0.11)$ and S4 $(0.18 \pm 0.14)$. There were no significance different in turbidity between stations (ANOVA, $\mathrm{p}>0.05$ ).

The Biological Oxygen Demand (BOD) levels in the water ranged from $0.5(\mathrm{~S} 2)$ to $9.8(\mathrm{~S} 1) \mathrm{mg} \mathrm{L}^{-1}$. There was no significant differences in BOD between stations (ANOVA, p>0.05). The chemical oxygen demand (COD) concentration was found in less than 20 $\mathrm{mg} \mathrm{\textrm {L } ^ { - 1 }}$ at all sampling station. There was no significance differences in COD concentration between the stations (ANOVA, $\mathrm{p}>0.05$ ).

Table 1: Mean water quality data and classification of water quality based on Malaysian Interim Water Quality Standard (INWQS), 2009 (Department of Environment, 2006)

\begin{tabular}{|c|c|c|c|c|c|c|c|c|c|c|c|c|c|}
\hline \multirow[b]{2}{*}{ Temperature } & \multicolumn{3}{|l|}{$\mathrm{S} 1$} & \multicolumn{3}{|l|}{$\mathrm{S} 2$} & \multicolumn{3}{|l|}{ S3 } & \multicolumn{3}{|l|}{$\mathrm{S} 4$} & \multirow[b]{2}{*}{ Class } \\
\hline & Mean & Min & Max & Mean & Min & Max & Mean & Min & Max & Mean & Min & Max & \\
\hline Temperature $\left({ }^{\circ} \mathrm{C}\right)$ & 29.30 & 28.21 & 30.44 & 30.07 & 27.22 & 32.90 & 27.69 & 26.85 & 31.60 & 28.09 & 27.20 & 32.90 & III \\
\hline $\mathrm{pH}$ & 3.80 & 3.70 & 3.84 & 3.74 & 3.67 & 4.19 & 3.68 & 3.03 & 4.07 & 3.68 & 3.03 & 4.07 & III \\
\hline $\mathrm{DO}\left(\mathrm{mg} \mathrm{L}^{-1}\right)$ & 3.99 & 2.25 & 7.86 & 4.34 & 2.35 & 8.15 & 3.02 & 1.99 & 8.02 & 4.13 & 3.48 & 4.86 & III \\
\hline Conductivity $\left(\mu \mathrm{S} \mathrm{cm}^{-1}\right)$ & 77.49 & 74.55 & 82.13 & 83.43 & 20.12 & 98.72 & 88.40 & 58.35 & 95.85 & 63.07 & 42.07 & 64.77 & I \\
\hline Turbidity (NTU) & 2.78 & 0.60 & 9.80 & 5.33 & 1.00 & 14.80 & 2.67 & 0.90 & 8.50 & 1.27 & 0.30 & 2.20 & I \\
\hline $\mathrm{NH} 3-\mathrm{N}\left(\mathrm{mg} \mathrm{L}^{-1}\right)$ & 0.32 & 0.20 & 0.47 & 0.18 & 0.01 & 0.49 & 0.18 & 0.07 & 0.47 & 0.18 & 0.04 & 0.51 & III \\
\hline $\mathrm{BOD}\left(\mathrm{mg} \mathrm{L}^{-1}\right)$ & 3.77 & 0.70 & 9.80 & 3.36 & 0.50 & 4.10 & 3.56 & 1.10 & 6.40 & 3.75 & 0.50 & 6.90 & III \\
\hline $\operatorname{COD}\left(\mathrm{mg} \mathrm{L}^{-1}\right)$ & 10.00 & 0.00 & 10.00 & 8.33 & 0.00 & 10.00 & 10.66 & 0.00 & 16.00 & 10.66 & 0.00 & 17.00 & I \\
\hline $\operatorname{TSS}\left(\mathrm{mg} \mathrm{L}^{-1}\right)$ & 9.05 & 1.00 & 28.00 & 8.72 & 1.00 & 23.00 & 4.88 & 1.00 & 14.00 & 11.44 & 1.00 & 54.00 & I \\
\hline WQI & III & & & II & & & II & & & II & & & \\
\hline
\end{tabular}




\section{DISCUSSION}

The water quality parameters recorded can be categorized according to the Malaysian Interim Water Quality Standard (INWQS); conductivity (Class I), DO (Class III-IV), $\mathrm{pH}$ (Class III) and turbidity (Class I-II) (Table 1). These parameters are considered in normal range condition except for $\mathrm{DO}$ and $\mathrm{pH}$ which are exhibit typical characteristics of peat swamp water with low DO and acidic water condition. Similar conditions for $\mathrm{pH}$ and $\mathrm{DO}$ were reported in Bebar River, Pahang with $\mathrm{pH}$ ranging from $3.53-4.55$, DO $0.54-1.76 \mathrm{mg} \mathrm{L}^{-1}$ (Gasim et al., 2007). Other example is the $\mathrm{pH}$ for blackwater river in central Sumatran that ranged from 4.4-4.7 (Baum et al., 2007).

The water temperature found in this study was relatively high (Class II). The water temperature could be influenced by the lack of canopy cover, its shallowness and stagnant water condition in the area. Tropical peatlands have high temperatures compared to area that experience cool seasonal climate (Satrio et al., 2009a).

There are many factors influence the temperature of water in river include the exchange of the heat on surface of the earth that is control by radiation, a movement of the groundwater, a chemical and a thermonuclear processes that occur in aquifer. The water also has an ability to hold the oxygen and it is also act as a solution for inverse proportional to the water temperature. As an example, more cooler the temperature of water, the more of dissolved oxygen it able to hold (Drever, 1997).

The area of peat swamp is known by low water $\mathrm{pH}$ values and has extreme acidic environment (Satrio et al., 2009b). Acidification process occurs in the peat. It is cause by the pyrite oxidation where pyrite reacts with oxygen and water to discharge the acidity, sulfate and iron (Klapper et al., 1996). The value of river water $\mathrm{pH}$ in this study was found below $5 \mathrm{mg} \mathrm{L}^{-1}$ (Class III). River water with $\mathrm{pH}$ values below 5.5 are in risk water condition (Wust and Bustin, 2004).

A very low concentration of DO was found in this study (Class III). The main cause is the discharge and pressure of the high content of organic matter that causes lack of oxygen in the water (Das and Acharya, 2003; Yisa and Jimoh, 2010). The shallow parts of the river were overgrown with some of aquatic plants. These aquatic plants provide some degree of aeration to the water through photosynthesis in some of the area and such the level of DO in the river was higher, an example is in station 4.

The DO levels in river water should be high and enough for the normal life of all species of the aquatic organisms. If the DO is not enough, all these organisms will be under pressure, death and life would not exist in that river stream (Smith, 2004). Oxygen is very important and necessary to improve the microbial sulfur oxidation process (Seidel et al., 2005).

The ammonia concentration in this study is categorized as Class II. Although all water samples collected recorded higher value of ammonical nitrogen concentrations, however they were below the maximum permissible limit set by World Health Organization (1998). The INWQS recommended maximum threshold level of ammonical nitrogen to support aquatic life for Malaysian rivers is $0.90 \mathrm{mg} \mathrm{L}^{-1}$. Improper management of sewerage services especially waste from palm oil mill is the main contributors to increase the ammonia level in the river water. Ammoniacal nitrogen can present in two forms which are monochloramines and discholomines with chlorine (Mohamad, 1993).

The BOD concentration was categorized as Class III. BOD is the total dissolve oxygen required by bacteria for decaying process under aerobic condition. It also the best indicator in determine oxygen pressure in consequence of organic pollution of aquatic organisms living. The value of BOD will continuously increase because of natural plant decaying process and other contributors that increase the total nutrient in water bodies such as construction effluent, fertilizer, animal farm and septic system (Hamzah, 2007). BOD concentration is directly related to DO concentrations. High value of BOD show decline in DO. This phenomenon is common as identified in many previous researches (Metcalf and Eddy Inc., 2002; Waziri and Ogugbuaja 2010).

Turbidity, TSS, COD and conductivity were all categorized as Class I, which indicated good water quality conditions. The turbidity of 5-25 NTU is still acceptable for domestic use (Drever, 1997). TSS value less than $30.0 \mathrm{mg} \mathrm{L}^{-1}$ was considered as low value and TSS more than $50.0 \mathrm{mg} \mathrm{L}^{-1}$ is considered as high value. TSS associated with soil erosion in the river. TSS value was also different each other in different river. Some TSS value is less than $5 \mathrm{mg} \mathrm{L}^{-1}$ and there are also reach of up to $30,000 \mathrm{mg} \mathrm{L}^{-1}$ in some river. TSS not only act as an indicator to soil erosion in the river; but also linked to transport by river include the nutrients and the metals and chemicals from the industrial factory and the chemicals that use in agricultural activity (Un GEMS/Water, 2005). The turbidity also acts as $n$ important indicator for organic pollution, the run-off of suspended material and heavy rain fall in the area (Yisa and Jimoh, 2010).

The deteriorating of water quality can be measured with high value of COD and lower value of COD 
represents the other way around (Sawyer et al., 2002). The low concentration of COD value in this research proved that the river water at the study area was not polluted with oxidizable organic or inorganic pollutants (Yisa and Jimoh, 2010). Conductivity is also affected by temperature; the warmer the water, the higher the conductivity. The low value of conductivity indicated the absence or low concentration of dissolved salts in the river water (Abdullah and Musta, 1999).

\section{CONCLUSION}

This study showed that the physical-chemical parameters of water in Batang Igan peat swamp forest were in normal range or in class I and class II that is considered good water quality status except for $\mathrm{pH}$ and dissolved oxygen for the water; however it is normal for peat water. The WQI for the water of the study area was found to be under class III (medium water quality) at station 1 and class II (good water quality) at station 2, station 3 and station 4 respectively.

All agencies involved should be more effective in preserving and maintaining the peat swamp forests to prevent the destruction of the peat swamp forest ecosystem.

\section{ACKNOWLEDGEMENT}

The authors wish to thank Forest Department of Sarawak, Sarawak Forestry Corporation and New Times Resources Sdn. Bhd for permission, help and support during research. Thanks also to Mr. Awangku Nizam Bin Awang Saberan for help and guidance in laboratory. Special thanks to Sarawak Meteorological Department for providing rainfall data.

\section{REFERENCES}

Abdullah, M.H. and B. Musta, 1999. Phreatic water quality of the Turtle Island of West Malaysia: Pulau Hill Inc. New York. Selingan Pulau Bakungan Kechil. Borneo Sci., 6: 1-9.

APHA, 2005. Standard Methods of Water and Wastewater. 21st Edn., American Public Health Association, Washington, DC., ISBN: 0875530478, pp: 650.

Baum, A., T. Rixen and J. Samiaji, 2007. Relevance of peat draining rivers in central Sumatra for the riverine input of dissolved organic carbon into the ocean. Estuar. Coast. Shelf Sci., 73: 563-570. DOI: 10.1016/j.ecss.2007.02.012

Das, J. and B.C. Acharya, 2003. Hydrology and assessment of lotic water quality in Cuttack City, India. Water, Air Soil Pollut., 150: 163-175. DOI: 10.1023/A:1026193514875
Department of Environment, 2006. Water quality index. Department of Environment.

Drever, J.I., 1997. The Geochemistry of Natural Waters: Surface and Groundwater Environments. 3rd Edn., Prentice Hall, New Jersey, ISBN: 0132727900, pp: 436.

John, E., 2005. Fearing the Worst for Borneo. New Straits Times. http://findarticles.com/p/newsarticles/new-straits-times/mi_8016/is_20050821/fearingborneo/ai_n44303706/

Hamilton, L.S., 2005. Forest and water. A thematic study prepared in the framework of the Global Forest Resources Assessment. Food and Agriculture Organization of the United Nation. ftp://ftp.fao.org/docrep/fao/011/i0410e/i0410e01.pdf

Gandaseca, S., Sabang, O.H. Ahmed and N.M.A. Majid, 2009. Vegetation assessment of the characteristics of saturated wetland soil and well drained forest soil. Am. J. Agric. Biol. Sci., 4: 167-172. 10.3844/ajabsp.2009.167.172

Gasim, M.B., B.S. Ismail, E. Toriman, S.I. Mir and C.C. Tan, 2007. A physico-chemical assessment of the Bebar River Pahang, Malaysia. Global J. Environ. Res., 1: 7-11. DOI: 10.3923/jbs.2009.730.737

Gupta, P.K., 2009. Methods in Environmental Analysis Water, Soil and Air. 1st Edn., Agrobios, India, ISBN: 9788177543087, pp: 433.

Hamzah, N. 2007. Assessment on water quality and biodiversity within Sungai Batu Pahat. M.Sc. Thesis, University Technology Malaysia. http://eprints.utm.my/6416/

Ingram, H.A.P., 1983. Hydrology. In: Ecosystems of the World, 4A, Mores--Swamp, Bog, Fen and Moor, Gore, A.J.P. (Ed.). Elsevier Scientific Publishing Company, New York, pp: 67-158.

Klapper, H., W. Geller and M. Schultze, 1996. Abatement of acidification in mining lakes in Germany. Lakes Reservoir: Res. Manage., 2: 7-16. DOI: 10.1111/j.1440-1770.1996.tb00043

Mohamad, M., 1993. Problems in the management of rivers for drinking water supply: Case studies. Proceeding of the International Symposium Management of Rivers for the Future, (MRF'93), UPM, Kuala Lumpur, pp: 16-18.

Metcalf and Eddy Inc., G. Tchobanoglous, F.L. Burton and H.D. Stensei, 2002. Wastewater Engineering: Treatment and Reuse. 4th Edn., McGraw-Hill Higher Education, New York, ISBN: 10: 007124140X, pp: 1408.

Maznah, W.O. and Mashor, M., 2002. Aquatic pollution assessment based on attached diatom communities in the Pinang River Basin, Malaysia. Hydrobiologia 487: 229-241. 
Salimin, M.I., S. Gandaseca, O.H. Ahmed and N.M.A. Majid, 2010. Comparison of selected chemical properties of peat swamp soil before and after timber harvesting. Am. J. Environ. Sci., 6: 164-167. DOI: 10.3844/ajessp.2010.164.167

Satrio, A.E., S. Gandaseca, O.H. Ahmed and N.M.A. Majid, 2009a. Effect of precipitation fluctuation on soil carbon storage of a tropical peat swamp forest. Am. J. Applied Sci., 6: 1484-1488. DOI: 10.3844/ajassp.2009.1484.1488

Satrio, A.E., S. Gandaseca, O.H. Ahmed and N.M.A. Majid, 2009b. Influences of chemical properties on soil carbon storage of a tropical peat swamp forest. Am. J. Applied Sci., 6: 1969-1972. DOI: 103844/ajassp2009.1969-1972

Sawyer, C., P. McCarty and G. Parkin, 2002. Chemistry for Environmental Engineering and Science. 5th Edn., McGraw-Hill, New York, ISBN: 0072480661, pp: 768.

Smith, J.M., 2004. Water quality trends in the Blackwater River Watershed Canaan Valley, West Virginia. M.Sc. Thesis, West Virginia University. http://gradworks.umi.com/14/24/1424039.html

Seidel, H., K. Gorsch and A. Schumichen, 2005. Effect of oxygen limitation on solid-bed bioleaching of heavy metals from contaminated sediments. Chemosphere, 65: 102-109. DOI: 10.1016/j.chemosphere.2006.02.022
UN GEMS/Water, 2005. Suspended solids and water quality. National Water Research Institute Burlington. http://www.gemswater.org/atlasgwq/solids-e.html

United Nations Development Programme, 2006. Malaysia's peat swamp forests conservation and sustainable use. UNDP. http://www.undp.org.my/malaysias-peat-swampforests-conservation-and-sustainable-use

Wust, R.A.J. and R.M. Bustin, 2004. Late Pleistocene Environmental Engineering. 3rd Edn., McGrawHill and Holocene Development of the Interior Peat-Book Co., New York, pp: 192.

World Health Organization, 1998. Guidelines for Drinking Water Quality. 2nd Edn., WHO, Geneva, ISBN: 9241545143, pp: 200.

Waziri, M. and V.O. Ogugbuaja, 2010. Interrelationship between physicochemical water pollution indicators: A case study of River Yobe-Nigeria. Am. J. Sci. Ind. Res., 1: 76-80. http://scihub.org/AJSIR/PDF/2010/1/AJSIR-1-176-80.pdf

Yisa, J. and T. Jimoh, 2010. Analytical studies on water quality index of River Landzu. Am. J. Applied Sci., 7: 453-458. DOI: 10.3844/ajassp.2010.453.458 